\title{
1
}

\section{Place-Based Land Use Planning and Development in Northern Australia: Cape York Peninsula, Queensland}

\author{
Sharon Harwood and Benjamin Christie-Johnston
}

The purpose of this chapter is to describe how urban and regional planning practice applied to the creation of development plans reinforce social and economic dislocation in remote settlements in Northern Australia. This chapter examines the range of planning policies that affect regional planning and development in remote Queensland using the Cape York region as a case study. The planning literature readily acknowledges that regional economies and land use planning are inter-related, yet little is known about how a change in land use regulation may affect the performance of local and regional economies (Kim, 2011). In urban and regional planning the interaction between regional economies and land use have traditionally been considered through a top-down approach (Kim, 2011). The literature regarding planning for economic development in remote regions in Australia (Harwood et al., 2011) and Canada (Markey et al., 2006, 2008, 2012) highlight the inadequacies of top-down and industry sector-based approaches in favour of a placebased approach, yet the practice of place-based planning remains elusive. This chapter analyses the implications of contemporary planning practice on development opportunities for the Aboriginal people of Cape York in Queensland and provides a conceptual framework for a place-based approach to land use planning for future application. 


\section{Introduction}

This chapter applies the 'haves' (decision-makers in the urban core) and 'have-nots' (affected communities in the periphery) analogy created by Taylor et al. (2011) to illustrate the need for alternative approaches to planning and development in remote townships and communities in Northern Australia using Cape York as an example. Taylor et al. (2011, p. 14) argued there is a high risk of the continuation of a bifurcated society in Northern Australia between the 'haves' and 'have-nots' from current policies and proposals to develop the north. Bifurcated in this context infers that development is concentrated in the urban centres, while rural and remote populations become vulnerable from a lack of development. This vulnerability is exacerbated from the export of social and natural capital from rural and remote regions that is only partially compensated by return flows of financial capital from national beneficiaries (e.g. welfare transfers). Taylor et al. (2011) suggested that larger development projects in the north have fallen well short of their stated intentions and benefited a small but elite group of 'haves' (e.g. owners and operators associated with the resource sector), while many of the local long-term residents, including the Indigenous residents, are relegated to a group of 'have-nots'.

Northern Australia is not a homogenous region. Rather, it is a collection of regions and local communities north of the Tropic of Capricorn, each with their own set of unique characteristics. Development should logically follow on from planning activities; however, there are varied and at times opposing views on development that obscure the realisation of community aspirations for the way in which their settlements are spatially arranged and economies are transformed. Altman (2013, p. 13) maintained there is a tendency to interchange the words 'development' and 'growth' and that they connote very different concepts. Development is generally associated with production and wealth creation, but it can also connote improvements in social wellbeing, living standards and opportunities. Altman also argued that often the real social and cultural costs of development are borne by the 'poorest and least powerful'.

Australian Indigenous people own much of Northern Australia under land rights and native title laws that account for 48 per cent of the 3 million $\mathrm{km}^{2}$ of land north of the Tropic of Capricorn (Altman, 2014). In the Cape York Peninsula, this rate is much higher at 98 per cent (Shannon Burns, Cape York Land Council, personal communication, 22 January 2018). 
This suggests that all future development in Northern Australia and Cape York specifically will need to be carefully negotiated with Indigenous landowners. Despite their significant ownership, government policy continues to apply (albeit unsuccessfully) urban-centric and 'western industrialised' standards upon the people who inhabit these mostly remote locales (Harwood et al., 2011). There is a plethora of federal government policy (e.g. COAG, 2008, 2009) aimed at reducing the inequality in social wellbeing and economic conditions experienced by Indigenous Australians living in remote communities. However, none of this policy has addressed the role of statutory planning initiatives, rather, the focus has been on securing local economic development in remote communities via home ownership. To this end, the COAG, through the National Partnership on Remote Indigenous Housing, has focused on supporting the states and territories of Australia to implement changes to their land legislation that would resolve tenure issues on community-titled land. The COAG (2014) also agreed to implement mainstream land planning and administration systems and comparable local government services in remote areas.

In the absence of any policy or intellectual thought on how planning in remote regions should consider the residents of the region under investigation, the planning profession tends to apply one of two theoretical approaches to regional planning practice. One approach is to gain economic efficiencies through the spatial organisation of predominantly urban areas and the other is to address problems associated with backward areas in industrially advanced nations (Harwood et al., 2011).

Northern Australia has experienced a combination of both of these approaches. For instance, the Far North Queensland Regional Plan (State of Queensland, 2009) applies the smart growth model (Duany et al., 2011) to its region to identify infrastructure efficiencies through the spatial organisation of its urban areas. Those lands outside the urban footprint are zoned for one of two purposes-rural production or environmental protection. The Kimberley Regional Planning and Infrastructure Framework (Western Australian Planning Commission, 2015) primarily identifies critical physical infrastructure (utility and transport) required to support the region's resource economy and its associated settlements. Surprisingly, little attention is paid to the quality and quantity of the community infrastructure required to sustain the liveability of the settlements in this region. An analysis by Harwood et al. (2016) of the 2014 Cape York Regional Plan found that instead of 
addressing the goals and aspirations of the Indigenous people of the Cape York region, the plan focused on how the state government would manage its economic intentions for the region. The plan was silent on the needs and aspirations of the Aboriginal landowners and residents. Moreover, the zoning contained within the plan focused on large-scale resource developments and the locking up of land from resource development by making these national parks and conservation zones or wilderness areas. This is not to say that environmental protection is not warranted; however, this form of 'exclusionary zoning' focuses on what cannot be developed as opposed to addressing the long-term sustainability of the townships or communities themselves. Planning in this context fails to identify and promote a balanced approach to economic development (location, type, scale and intensity) and environmental protection.

The approaches taken by both the West Australian and the Queensland governments to development planning has been to achieve infrastructure efficiencies for their respective governments. What appears to be missing is a focus on increasing the liveability of these regions. It appears that the purpose of these development plans is to create a strategic investment plan for government relative to economic returns from private sector development contributions, rather than support the development of selfsustaining communities.

\section{Planning in Remote Regions}

Harwood et al. (2016) maintained that the spatial territory of a remote region is typically defined by the range of 'problems' they share. For instance, the regional plans for the Cape York Peninsula region in northern Queensland and the Nunavut Territory in northern Canada identify their limitations to realising economic development opportunities as being a combination of:

- small population and local market base

- remoteness of the location and limited infrastructure

- limited financial and technical capacity and capability of the population

- climatic conditions (that is, extremes that impair all-weather access)

- increasing global demand for goods and/or services and the high cost of transporting goods to market (State of Queensland, 2014; Nunavut Planning Commission, 2014). 
It would appear that simply being included in a remote sparse region with a challenging climate is an impediment to stimulating economic development. By this it is inferred that economic development in remote regions is constrained due to a range of locational factors including a highly dispersed population-except, of course, where mining is concerned. This form of development is dependent on private sector investment, as opposed to government, to facilitate. However, as Harwood et al. (2016) and Dale (2014) asserted, the narrative of any story depends on who is telling the story. Therefore, it is crucial that the narrative of any plan reflects the lived experiences of the community that the plan is intended to serve (as opposed to the urban cores or industrial resource firms), especially in remote locations.

There is a significant disjuncture between planning and development for remote regions. Moreover, there is no literature to describe the relationship between development, planning and the circumstances that some communities face in remote settlements (Dillon Consulting, 2012) and in Northern Australia (Harwood et al., 2011). The current approach, while described as top down by some, is known in land use planning literature as the core-periphery model (Harwood et al., 2011). The core-periphery model describes the spatial economic organisation of the leading urbanised core and the lagging rural periphery (Moore, 1994). Peripheral areas often experience lagging growth or stagnation and rely on the growth driven by the urban core in the form of increased demand for unprocessed resources located in the periphery (Friedmann, 1966) and provide capital to support growth opportunities (Harwood, 2010). The core areas are industry and knowledge-driven, as opposed to resource dependent, for growth (Smith \& Steel, 1995). The application of the core-periphery model exacerbates the gap between the 'haves' and the 'have-nots', which in turn supports the bifurcation of societies in Northern Australia.

The core-periphery model is premised upon the possibility that a mature regional economic system may eventually bridge the development gap between the urban and peripheral regions (Moore, 1994); however, the reality is very different. Resource peripheries tend to remain on the economic (and social) margin as their development paths become locked in and the periphery remains dependent on demand, investment and decision-making from the core (Carson et al., 2010; Harwood et al., 2011). 
Government offices located in Australia's periphery (i.e. Cairns, Townsville, Darwin and Broome) often become the executive arms of the external investing core as they seek continued investment from the core (see, for example, how Darwin responds to resource development proposals in Carson et al., 2010). As a result, decision-makers are inclined to favour decisions that may lead to fast economic growth in the core but not necessarily sustainable development in the periphery (Barnes et al., 2001). Taylor et al. (2011) concluded that improving quality of life for the 'have-nots' (including those located within and beyond the resource periphery) will require large investments and a substantial reconsideration of the way in which economic development is envisaged. Current regional development practices indicate that neither is occurring as most investment is market-driven and involves large governmentfunded projects that derive large rents received from resource extraction that are not matched by investments in human capital by those industries (Taylor et al., 2011).

Spatial planning theory and practice within the urban centre is essentially related to and has evolved from the management of change within complex urban and industrial systems and the political and legislative processes that govern the change in land uses (Selman, 1995). By comparison, remote areas have been neglected in relation to planning theory and practice. This may be attributed to a perception by planners that non-metropolitan areas possess less complex and competitive economic structures associated with primary industries and the mining sector. Planning practice in remote areas continues to unsuccessfully apply urban planning models and approaches (Markey et al., 2006; Harwood et al., 2011; Harwood et al., 2016).

Markey et al. (2006) maintained that the application or misapplication of development notions from urban settings is particularly problematic for remote areas. This misapplication creates development strategies for remote areas that reinforces the existing urban-based industrial resource economy and dependence on external capital and business opportunities for remote communities (Markey et al., 2006). This is particularly evident in Cape York and, as a consequence, has created a bifurcated society where mining development has created significant wealth for some (e.g. Weipa) and minimal benefits for the people living in Aboriginal settlements such as Mapoon, Aurukun and Napranum. Table 1.1 shows a comparison of Aboriginal settlements and the mining town of Weipa in the western region of Cape York. 
Table 1.1: Comparison of western Cape York settlements.

\begin{tabular}{|l|c|c|c|c|c|}
\hline Settlement & $\begin{array}{c}\text { Total } \\
\text { population }\end{array}$ & $\begin{array}{c}\text { Indigenous } \\
\%\end{array}$ & $\begin{array}{c}\text { Unemployed } \\
\text { \% }\end{array}$ & $\begin{array}{c}\text { Attained } \\
\text { year 11/12 } \\
\%\end{array}$ & $\begin{array}{c}\text { Non-school } \\
\text { qualification } \\
\%\end{array}$ \\
\hline Weipa & 3,951 & 18.6 & 2.9 & 52.7 & 62.5 \\
\hline Aurukun & 1,435 & 92.2 & 84.8 & 16 & 29 \\
\hline Napranum & 993 & 95.9 & 30 & 31.7 & 17.8 \\
\hline Mapoon & 312 & 89.1 & 29.6 & 25.2 & 33.7 \\
\hline Queensland & $4,853,048$ & 3.6 & 6.1 & 55.3 & 54.2 \\
\hline
\end{tabular}

Source: State of Queensland (2017b).

The 'haves' of Weipa are employed, mostly non-Indigenous and have attained a higher level of education and/or non-school qualification. The benefits from mining have not positively affected the neighbouring Aboriginal settlements of Mapoon, Napranum and Aurukun.

Remote settlements are less connected to the urban and rural sectors, possess diverse histories and are incredibly complex due to the interface with cultural, land tenure, environmental values and land management issues that do not fit easily into an urban-based planning system. Therefore, a new remote-planning paradigm based on the concept of place must be created that addresses the unique characteristics of Northern Australia.

\section{Cape York Region}

This chapter examines the Cape York Peninsula region to describe how the various planning outcomes have attempted to reduce the disparities between the urban core and the residents and communities in Cape York Peninsula. 


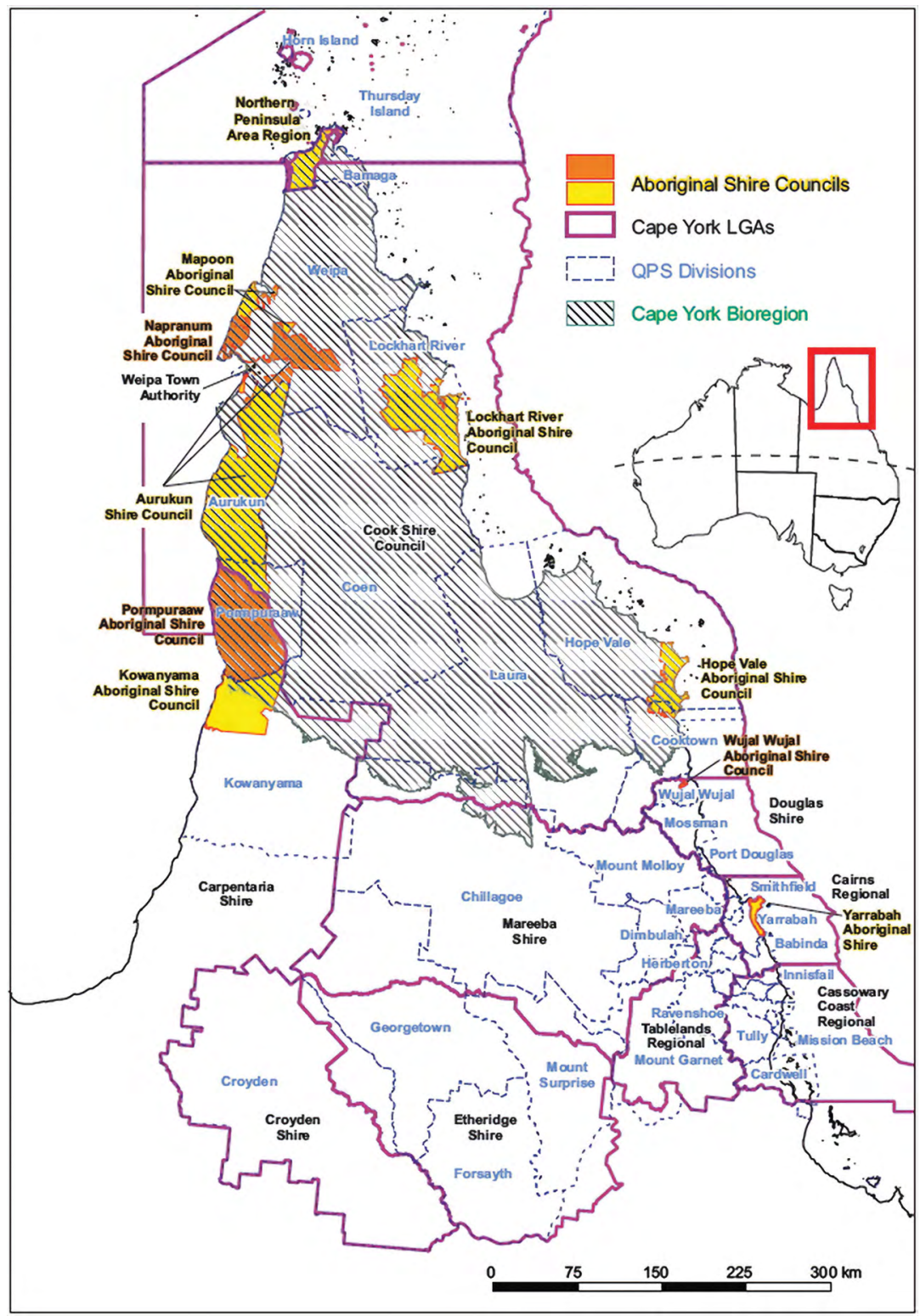

Figure 1.1: Cape York.

Source: Map created by Adella Edwards of Connect Spatial, Townsville, Queensland. 
The site characteristics of the Cape York Peninsula are highly contestable because of the way each entity conceptualises the values within. The spatial extent of the region defined as Cape York varies significantly (see Figure 1.1) and this in and of itself creates confusion for the people who live in the region. The land use regional plans in Queensland have entirely separate sets of boundaries to the state government departments (e.g. Police) and their associated service delivery. Exacerbating this disconnect in regional planning is a different spatial extent of the Cape York Peninsula Bioregion, which identifies the various land cover attributes, to the Cape York Regional Plan, which regulates how these land cover attributes can be used. The Torres Strait continues to be excluded from regional planning altogether and as a consequence is subjected to a series of local government plans.

Despite the various ways of conceptualising a region and spatially mapping its boundaries, the Cape York region is treated as a homogenous area when viewed from a southern urban perspective. This means a common feature of the entire region (with the exception of Weipa Township Area) is that it is an economically underperforming region - that is, dependent on welfare transfers from the core (see Appendix 1 for Socio-Economic Indexes for Areas [SEIFA] scores for each of the local government areas).

\section{Land Use Planning and Cape York Peninsula}

Land use planning policy and legislation in Australia is designed and controlled by each of the state/territory governments, with each possessing its own sets of legislation, policies and procedures that are a result of their own unique histories and types of developable resources. Typically each of the states/territories planning legislation has evolved from the regulation of the inner-city urban development and over time has been applied to areas outside of the city, for instance suburbs, rural lands and, more recently, remote areas.

There are three levels of planning affecting development in Queensland: state planning policies, regional plans and local government planning schemes. The state planning policy is a set of principles that describe the state's interests that must be considered in plan making and development assessment. There are 17 state interests (as of July 2017) arranged under 
five themes (State of Queensland, 2017a), some of which are mapped as constraints (e.g. natural hazards, coastal environment and vegetation) and some of which are not (e.g. tourism and mining). These 17 state interests and their relative locations cannot be ignored at either a regional or local level, and in some instances a potential development site can impact on multiple state interests, which means that the proposed development is essentially prohibited even where it may be locally appropriate. These state interests are mapped at a small scale and, therefore, are prone to be incorrect. To rectify or amend the relative location of a state interest involves specialist consultants to undertake extensive site analysis to determine whether the interest applies to the proposed development site and, if so, where and to what spatial extent. Moreover, the state interests are typically mapped as constraints, while development (tourism and mining) does not have a location on a map with statutory protection. While this is not to imply that development should be undertaken in an unsafe or environmentally irresponsible way, there does need to be some flexibility in the way in which a local community can decide how land could be used that first meet the aspirations of the local residents as opposed to the expectations of urban-based populations.

Regional planning in Queensland is undertaken at a jurisdictional level and, as a consequence, is a series of local government authorities sharing a common feature-for example, the North West Queensland region experiences low population density but high-intensity hard rock mining activities. The Cape York region is comprised of 11 local governments and is bounded as a region by the highly contestable environmental values of state significance (Dale et al., 2017), with a high Indigenous population and 10 of the 11 local governments referred to as Indigenous Local Governments (ILGs). These were once Aboriginal mission settlements that have over time become local government authorities in their own right. Over the past 20 or so years since the introduction of Native Title Act 1993 (Cth), ongoing Aboriginal connections to and with significant tracts of government-owned land in Cape York have been legally acknowledged in the Federal Court system. In many instances, the Queensland Government has assigned the ownership and title to lands that have been subject to exclusive native title determinations to the relevant Aboriginal corporate entity (e.g. a Prescribed Body Corporate or Land Trust). 
At the same time, another government policy was implemented to transition Aboriginal Community Councils to ILGs, and in Queensland this included mainstreaming land planning and administration systems. Those areas within the ILG jurisdiction that had native title extinguished were typically retained by the relevant local government, whereas the balance of the shire became owned and controlled by one or more Aboriginal corporate entities. For example, in Hope Vale Aboriginal Shire Council area, 99.5 per cent of the shire is owned, managed and controlled by the Hope Vale Congress Aboriginal Corporation (combined Land Trust and Prescribed Body Corporate), and 0.5 per cent of the shire is owned, managed and controlled by the local government. However, in this instance, the Council create plans for 100 per cent of the shire jurisdiction and are required to implement state planning policies as part of the statutory land use planning system.

\section{Local Government Planning}

Since the application of the COAG agreement to implement mainstream land planning and administrations systems in Queensland, most ILGs in Queensland have a statutory land use plan. At the time of making these plans, the Sustainable Planning Act 2009 (Qld) required a template approach (referred to as the Queensland Planning Provisions) be applied to plan making. These plans focused on infrastructure efficiencies and surveying existing house lots within the township zone, with the balance of the shire being designated as either Environmental Management and Conservation or Rural. There was scant attention or opportunity to undertake a comprehensive land cover assessment outside of the township zone. What has emerged from this concentration on the township is a comprehensive infrastructure plan (i.e. trunk water and sewerage) at the expense of considering future economic development options. It is also worth noting that while these plans were being developed, the land administration system was also transferring lands from the state to the relevant native title corporate entities. Stephenson (2009, p. 547) referred to this system as 'land rights legislation', whereby a statutory system is established for the transfer of inalienable freehold land to Indigenous people. A variety of systems exist in Australia (see Stephenson, 2009, for a comprehensive assessment), but in Queensland the land is transferred to an Aboriginal corporate entity that in turn holds the land in perpetuity on 
behalf of Indigenous people specifically concerned with the land. Native title rights and interests continue to be held and managed by the relevant Prescribed Body Corporate.

These two policy approaches inadvertently culminated to create two types of land holders in any given ILG area in Queensland. The local government typically assumes ownership of land and infrastructure within the township and the Aboriginal corporate entity (one or more) owns the lands zoned Rural or Environmental Management and Conservation as the balance of the shire territory. This has created angst for the Aboriginal landowning entities as they not only have to deal with the restrictions of a one-size-fits-all statutory land use plan (including land use definitions) but must also deal with the state planning policy that maps land for environmental values (e.g. vegetation) and hazards (e.g. coastal, flooding, etc.) that invariably constrain future development (see Harwood, 2014, for detailed analysis). This implies that lands within the township zone have been considered for future development, whereas the balance is owned by an Aboriginal corporate entity and contains highly constrained lands.

If the Aboriginal corporate entity has development aspirations, for example, creating an economic platform via a housing and construction industry on their own lands, then they are required to undertake a costly development application process associated with the mainstream planning system. This is, of course, after they have applied their own internal cultural governance protocols to identify a range of 'appropriate' land uses and the Prescribed Body Corporate administrative roles (including the granting of an Indigenous Land Use Agreement pursuant to the Native Title Act).

This process is financially prohibitive and involves lengthy timeframes that are not funded by government. The Aboriginal corporate entity as the 'developer' must also bear the costs of trying to amend the statutory system to better reflect their own aspirations for the use and management of their own lands. In essence, the Aboriginal corporate entity must repeat the planning role of the local government by undertaking an additional planning process for their own lands. An alternative system is required to enable development that allows the Aboriginal corporate entity's aspirations to be realised. 


\section{Place-Based Planning}

Land use planning is about how communities make decisions about the spatial allocation of resources and prioritise action strategies to meet predetermined objectives and outcomes. More specifically, Indigenous planning in a Northern Australia context has not yet been conceptualised from an Indigenous lens; rather, the urban-centric focus pervades, which perpetuates flawed planning outcomes for remote Indigenous communities. It would seem logical to align land use planning outcomes with the aspirations of the Indigenous landowners as opposed to mainstreaming the system to be comparable with predominantly nonIndigenous urban areas.

Place-based planning explicitly acknowledges the relationship between the people and the attributes of the space that they inhabit. People identify with a space, the parameters of which may transcend geopolitical boundaries and may be the result of an ongoing and enduring association with those geographical features. Associated with the place-based approach is a departure from the focus on industry sector development associated with economics and a move towards the delineation of a place as a spatial unit and the subsequently appropriate forms of development.

The concept of place is associated with the relationship between individuals, the space that they inhabit and the subsequent value that individuals associate with the attributes of that space. Tuan (1977) maintained that what begins as a space when imbued with value becomes a place. The concept of place reinforces that decision-making in planning for spatial transformation is value laden and reflects the values and beliefs of its inhabitants. Planning in remote locations as both a land use and decision-making process must consider the complex relationship between the physical environment and the manner in which the affected community perceives both themselves as individuals and as a community.

Therefore, spatial planning requires an understanding of the assets that an area possesses and whether these can be used to create a better future for its inhabitants and, if so, then how. Malczewski (2004) drew a distinction between the land cover attributes and the subsequent uses of these attributes. This distinction allows for two very important and often overlooked aspects of land use planning in remote regions. An inventory of the land cover attributes is necessary to understand how the local 
people value those attributes and how they may be used to improve their overall wellbeing. It is the values of the people who are connected to the space that should be respected in land use planning and decision-making.

More often than not, planning for remote areas starts with the extent of the geopolitical jurisdiction and then proceeds on the basis of how the region's natural resources can be exploited with little regard for how the local inhabitants may value those assets (Harwood et al., 2016). A place-based approach to planning would start with the local inhabitants, a land cover assessment, an overview of how the locals identify with the region as their place, how they value the land cover attributes and other natural assets, and the land uses that they may see as being vital for their long-term wellbeing.

Matunga (2013) described Indigenous planning as inherently place based because it links specific Indigenous communities to defined ancestral places, environments and resources and uses Indigenous (and other) knowledge to make decisions highly contextual to that community and how a community sees its own future. Indigenous planning is also place based because it implies a long and close association of the people with their traditional lands and, therefore, knowledge of the specific environment and what it can sustain (Matunga, 2013).

The Queensland division of the Planning Institute of Australia (2017) recently published an Indigenous planning policy that defines why a place-based approach that is embedded within a rights-based framework is required for application to the planning of the Indigenous estate in Queensland. More specifically, that Aboriginal and Torres Strait Islander peoples' knowledge, culture and tradition is held by them and that undertaking functions under the new Planning Act 2016 (Qld) will require developing a working relationship with Aboriginal and Torres Strait Islander peoples based on mutual trust and respect.

Figure 1.2 provides a schematic overview of the procedure that place-based planning should take and compares this to the way in which planning is currently undertaken in Queensland. 


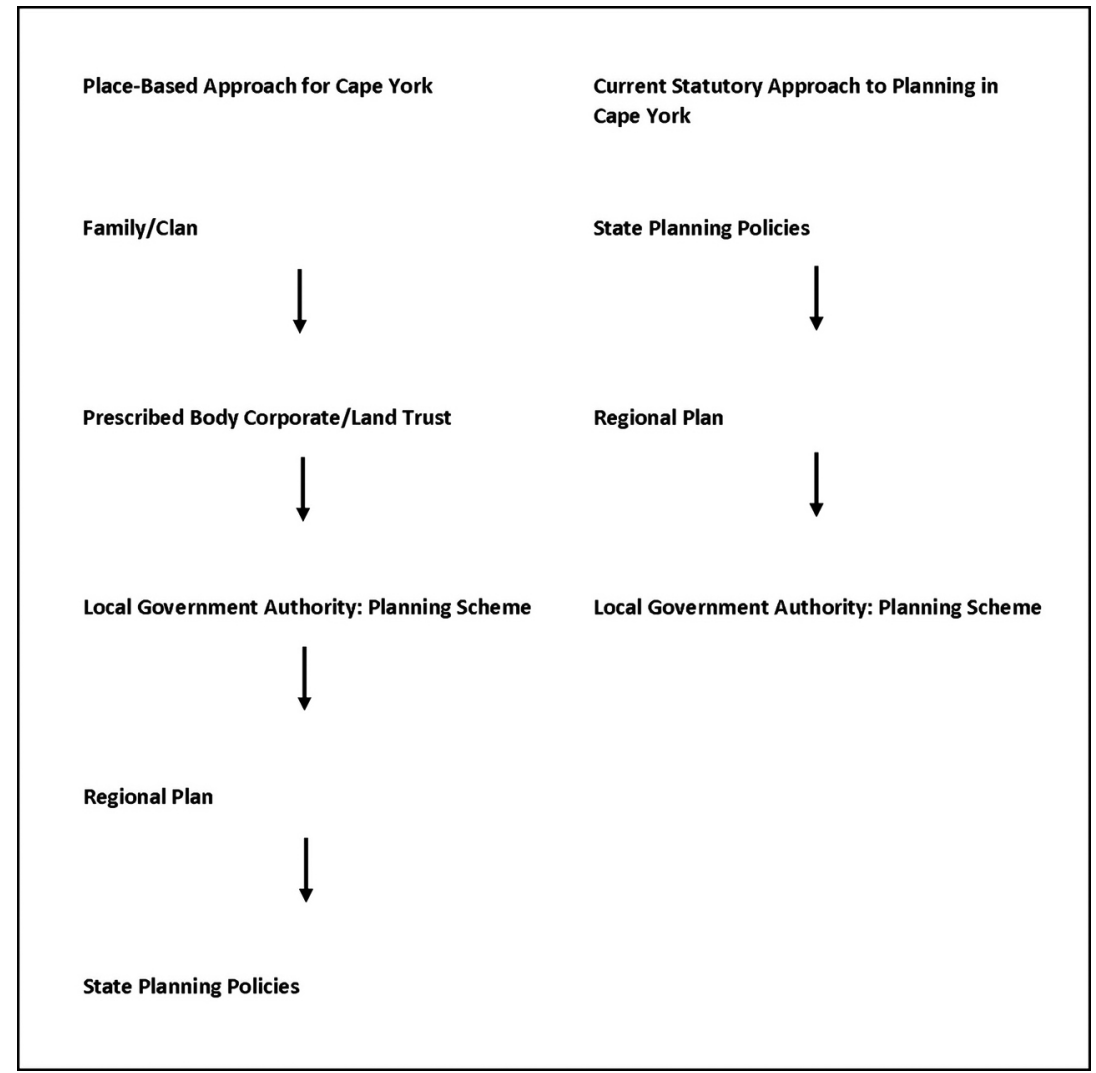

Figure 1.2: Proposed place-based planning procedure in Cape York versus the current statutory approach.

Source: Authors' research.

The place-based approach, as represented in Figure 1.2, acknowledges the social organisation and knowledge holders of the place that is being considered. This process also acknowledges that only the rightful owners of the native title rights are able to speak on behalf of the area being planned. This implies that local government planning approaches are not only ignorant of the cultural protocols about using land, but also the ways in which decisions are made by Indigenous families and their clan groups about using the land cover attributes (see Harwood, 2015, for an overview of how this system could work at a family/clan level). 


\section{Conclusion}

Referring back to the 'haves' and 'have-nots' analogy by Taylor et al. (2011), it becomes evident why the 'have-nots' are excluded from accessing the benefits of development. There is no consideration of both the social organisation and cultural obligations governing the Indigenousowned lands, nor is planning focused on what is an appropriate and inappropriate use of the land and land cover attributes. A fundamental shift in the way that planning is conceptualised in Northern Australia is required to ensure that statutory land use planning can transform the lives and environments of remotely located communities and, in particular, for Indigenous landowners and their associated corporate entities.

Harwood et al. (2016) found from their review of the Cape York Regional Plan that top-down sectoral-based approaches to planning do not necessarily work very well because they tend to be more externally driven rather than being internally driven. This is consistent with Taylor et al.'s (2011) findings regarding large resource developments and the benefit flows from these developments. It is critical to amend the planning system across Northern Australia to include place-based approaches that are bottom up to ensure that they are internally driven and reflect the values of the people that inhabit these locales. This new approach may necessitate the creation of a separate Indigenous planning statute for lands owned by Aboriginal corporate entities to enable development to reflect the landowner and native title holder aspirations. It would appear that Northern Australia and Cape York in particular will continue to experience a south ('haves') and north ('have-nots') bifurcation if they are unable to control the way in which Aboriginal corporate entities can use and protect their land estates.

\section{Appendix 1.1}

SEIFA is a measure of the social and economic conditions of areas across Australia. The SEIFA score is a composite score generated by the Australian Bureau of Statistics that ranks geographic areas according to socioeconomic disadvantage. The score considers low-income earners, education attainment, unemployment and dwellings without a motor vehicle. 
The results presented in Table A.1 indicate that all ILG areas experience 100 per cent disadvantage, whereas the mining town of Weipa experiences a disproportionate percentage of its population in the more advantaged quintiles (4 and 5).

Table A.1: SEIFA scores for Indigenous Local Government Areas in Cape York region.

\begin{tabular}{|l|c|c|c|c|c|}
\hline $\begin{array}{l}\text { Local } \\
\text { Area }\end{array}$ & $\begin{array}{c}\text { Quintile 1 (most } \\
\text { disadvantaged) }\end{array}$ & $\begin{array}{c}\text { Quintile } \\
\mathbf{2}\end{array}$ & $\begin{array}{c}\text { Quintile } \\
\mathbf{3}\end{array}$ & $\begin{array}{c}\text { Quintile } \\
\mathbf{4}\end{array}$ & $\begin{array}{c}\text { Quintile 5 (least } \\
\text { disadvantaged) }\end{array}$ \\
\hline Aurukun & 100 & 0.0 & 0.0 & 0.0 & 0.0 \\
\hline Cooktown & 70.2 & 26 & 3.8 & 0.0 & 0.0 \\
\hline Hope Vale & 100 & 0.0 & 0.0 & 0.0 & 0.0 \\
\hline Kowanyama & 100 & 0.0 & 0.0 & 0.0 & 0.0 \\
\hline Lockhart River & 100 & 0.0 & 0.0 & 0.0 & 0.0 \\
\hline Mapoon & 100 & 0.0 & 0.0 & 0.0 & 0.0 \\
\hline Mornington & 100 & 0.0 & 0.0 & 0.0 & 0.0 \\
\hline Napranum & 100 & 0.0 & 0.0 & 0.0 & 0.0 \\
\hline $\begin{array}{l}\text { Northern } \\
\text { Peninsula Area }\end{array}$ & 100 & 0.0 & 0.0 & 0.0 & 0.0 \\
\hline Pompuraaw & 100 & 0.0 & 0.0 & 0.0 & 0.0 \\
\hline Weipa & 0.0 & 0.0 & 0.0 & 85.4 & 14.6 \\
\hline Wujal & 100 & 0.0 & 0.0 & 0.0 & 0.0 \\
\hline QUEENSLAND & 20 & 20 & 20 & 20 & 20 \\
\hline
\end{tabular}

Source: State of Queensland (2017b).

\section{References}

Altman, J. (2013). Land rights and development in Australia: Caring for, benefiting from and governing the Indigenous estate. In T. Rowse \& L. Ford (Eds), Between Indigenous and settler governance (pp. 121-134). London, England: Routledge.

Altman, J. (2014, March). The political ecology and political economy of the Indigenous land titling 'revolution' in Australia. Maori Law Review, 1-17.

Barnes, T. J., Hayter, R. \& Hay, E. (2001). Stormy weather: Cyclones, Harold Innis and Port Alberni, BC. Environment and Planning A, 33(12), 2127-2147. 
Carson, D., Schmallegger, D. \& Harwood, S. (2010). A city for the temporary: Political economy and urban planning in Darwin, Australia. Urban Policy and Research, 28(3), 293-310.

Council of Australian Governments (COAG). (2008). National Indigenous reform agreement. Canberra, ACT: Commonwealth of Australia.

Council of Australian Governments (COAG). (2009). National Indigenous reform agreement. Canberra, ACT: Commonwealth of Australia.

Council of Australian Governments (COAG). (2014). National partnership on remote Indigenous housing - progress review (2008-2013). Canberra, ACT: Commonwealth of Australia.

Dale, A. (2014). Beyond the north-south culture wars: Reconciling Northern Australia's recent past with its future. Springer.

Dale, A., Potts, R. \& Harwood, S. (2017). Northern Australia: A contested landscape. In N. Sipes \& K. Vella (Eds), Australian handbook of urban and regional planning (pp. 86-97). Milton Park, England: Routledge.

Dillon Consulting. (2012, 15 June). Independent review: Draft Nunavut land use plan. Retrieved from assembly.nu.ca/library/Edocs/2012/000710-e.pdf

Duany, A., Speck, J., Lydon, M. \& Goffman, E. (2011). The smart growth manual. Sustainability: Science, Practice and Policy, 7(2), 89-90.

Friedmann, J. (1966). Regional development policy: A case study of Venezuela. Cambridge, MA: MIT Press.

Harwood, S. (2010). Planning for community based tourism in remote areas: Bird watching in Arfak Mountains West Papua (Unpublished doctoral thesis). Charles Darwin University, Darwin, NT.

Harwood, S. (2014, 16 June). Submission to the Aboriginal and Torres Strait Islander Land (Providing Freehold) and Other Legislation Amendment Bill 2014. Agriculture, Resources and Environment Parliamentary Committee.

Harwood, S. (2015). Submissions - COAG land investigation. Retrieved from pmc.gov.au/indigenous-affairs/land/coag-investigation-indigenous-landadministration-and-use/submissions

Harwood, S., Schmallegger, D. \& Prideaux, B. (2011). Social equity in regional development planning: Who plans for remote communities? Journal of Contemporary Issues in Business and Government, 17(1), 13-30. 
Harwood, S., Wensing, E \& Ensign, S. (2016). Place based planning for economic development in remote Aboriginal settlements. In A. Taylor, D. Carson, P. Ensign, L. Husky, G. Eilmsteiner-Saxinger \& R. Rasmussen (Eds), Settlements at the edge: Remote human settlements in developed nations (pp. 124-149). Cheltenham, England: Edward Elgar Publishing.

Kim, J. H. (2011). Linking land use planning and regulation to economic development: A literature review. CPL Bibliography, 26(1), 35-47.

Malczewski, J. (2004). GIS-based land use suitability analysis: A critical overview. Progress in Planning, 62, 3-65.

Markey, S., Halseth, G. \& Manson, D. (2006). The struggle to compete: From comparative to competitive advantage in Northern British Columbia. International Planning Studies, 11(1), 19-39.

Markey, S., Halseth, G. \& Manson, D. (2008). Challenging the inevitability of rural decline: Advancing the policy of place in northern British Columbia. Journal of Rural Studies, 24(4), 409-421.

Markey, S., Halseth, G. \& Manson, D. (2012). Investing in place: Economic renewal in northern British Columbia. UBC Press.

Matunga, H. (2013). Theorising Indigenous planning. In R. Walker, T. Jojola \& D. Natcher (Eds), Reclaiming Indigenous planning (pp. 3-32). Montreal, Canada: McGill-Queens University Press.

Moore, T. (1994). Core-periphery models, regional planning theory and Appalachian development. The Professional Geographer, 46(3), 316-331.

Nunavut Planning Commission. (2014). Draft Nunavut land use plan. Retrieved from www.nunavut.ca/land-use-plans/draft-nunavut-land-use-plan

Planning Institute Australia. (2017). PIA Queensland position statementAboriginal and Torres Strait Islander planning policy. Retrieved from www. planning.org.au/documents/item/8606

Selman, P. (1995). Theories for rural environmental planning. Planning Practice and Research, 10(1), 5-13.

Smith, C. \& Steel, B. (1995). Core-periphery relationships of resource-based communities. Community Development, 26(1), 52-70.

State of Queensland. (2009). Far North Queensland regional plan 2009-2031. Brisbane, Qld: Department of Infrastructure and Planning. 
State of Queensland. (2014). Cape York regional plan, Department of State Development, Infrastructure and Planning. Retrieved from dsdmipprd.blob. core.windows.net/general/cape-york-regional-plan.pdf

State of Queensland. (2017a, July). State planning policy. Department of Infrastructure, Local Government and Planning. Retrieved from dilgpprd. blob.core.windows.net/general/spp-july-2017.pdf

State of Queensland. (2017b). Queensland regional profile for Cape York region. Queensland Government Statistician's Office, Queensland Treasury.

Stephenson, M. (2009). To lease or not to lease? The leasing of Indigenous statutory lands in Australia: Lessons from Canada. Commonwealth Law Bulletin, 35(3), 545-570.

Taylor, A., Larson, S., Stoeckl, N. \& Carson, D. (2011). The haves and have nots in Australia's Tropical North-new perspectives on a persisting problem. Geographical Research, 49(1), 13-22.

Tuan, Y. (1977). Space and place: The perspective of experience. London, England: Edward Arnold.

Western Australian Planning Commission. (2015). Kimberley regional planning and infrastructure framework. Perth, WA: Department of Planning. 
This text is taken from Leading from the North: Rethinking Northern Australia Development, edited by Ruth Wallace, Sharon Harwood, Rolf Gerritsen, Bruce Prideaux, Tom Brewer, Linda Rosenman and Allan Dale, published 2021 by ANU Press, The Australian National University, Canberra, Australia.

doi.org/10.22459/LN.2021.01 